\title{
Perhócs Péter
}

\section{A dıvattermelés köruonalaı'}

\author{
Divattermékek, kulturálıs kontextusok \\ és szımbolıkus jelentéskonstrukció
}

\section{Bevezetés}

Az elmúlt évtizedekben a fogyasztók ízlésváltozásának és vásárlóerejük megnövekedésének hatására, a termelés radikális átalakulásának (Szabó és Kocsis 2002), a mindennapi élet egyre jelentősebb esztétizálódásának (Featherstone 1991; Lash és Urry 1994), s ezen keresztül a kulturális termékipar térhódításának (Hesmondalgh 2013; Garnham 2005; Nixon 2003; Pratt 2004; Power és Scott 2004) lehettünk tanúi. Manapság jóformán már nincs olyan szegmense a fogyasztási javak piacának, amelyben ne kapna kitüntetett szerepet az esztétikum: a fogyasztók a termékeket esztétikai alapon értelmezik, valamint megválasztásuk is esztétikai kritériumok mentén történik (Featherstone 1991; Lury 1996). A posztmodernnek címkézett fogyasztáselméletek szerint éppen emiatt a termékek értékelésében, valamint a vásárlási döntések meghozatalában egyre jelentősebb szerep jut a szimbolikus tulajdonságoknak, mi több, a fogyasztás tárgya immár nem a termékhez tartozó alapfunkció, hanem az általa hordozott szimbolikus jelentés (Baudrillard 1981; Featherstone 1991; Hischmann 1981). A divatpiac a kulturális termékek piacának egyik legeklatánsabb példáját testesíti meg, ugyanis a piac e szegmensében a termékekhez tartozó szimbolikus érték jóval felülmúlja a hozzájuk tartozó használati értéket (du Gay és Pryke 2002). ${ }^{2}$ Hangsúlyozandó ugyanakkor, hogy a divattermékek szimbolikus értékének megalkotója és kitermelője nem pusztán a termék közvetlen előállítója, valamint hogy a produktumokhoz tartozó szimbolikus jelentés

1 Köszönöm Kuczi Tibor, Havas Ádám és szakmai bírálóm kéziratomhoz füzött kritikai és segítő szándékú megjegyzéseit.

2 Kulturális és/vagy esztétikai javak alatt elsősorban azokat a termékeket értem, melyek fogyasztása nem hasznossági, hanem inkább szimbolikus alapokon szerveződik, s melyek gazdasági értéke jobban függ azok szimbolikus, mint funkcionális értékétől (O’Connor 2010; Power és Scott 2004). 
nem az adott darab materiális tulajdonságaiból származtatható (Hirschmann 1981, 1986). ${ }^{3}$ E tanulmány egy hosszabbnak ígérkező kutatás első eredménye, melynek alapkérdése: miként konstruálódik meg a divattermékekhez tartozó szimbolikus jelentés? Továbbá, hogy milyen szerepet töltenek be a divatmárka által kialakított üzenet közvetítésében azok a kulturális kontextusok, amelyekben a piaci közvetítők és a potenciális vásárlók a divatproduktumokat érzékelik és értékelik. ${ }^{4}$

A következőkben arra igyekszem rámutatni, hogy a különböző állomások - vagy, ahogy a továbbiakban hivatkozom rájuk: fázisok -, úgymint a divatbemutatók, a divatmagazinok, valamint az értékesítési színterek olyan kulturális kontextusok, melyekben a divattermékek szimbolikus jelentéssel gazdagodnak. Az alábbi bevezető tanulmány főbb céljai között éppen emiatt annak a termékpályának a széles ecsetvonásokkal történő felvázolása szerepel, amely során a divattervező kezei közül kikerülő kreációk - ruhadarabok, cipők, táskák és egyéb kiegészítők - a fentebb megnevezett fázisokon áthaladva szimbolikus tartalommal itatódnak át. A tanulmány célkitüzése tehát nem a jelentés monopolizálásáért folyó szimbolikus küzdelmek relációs logikájának a megragadása, hanem - alapvetően egy diakrón logika mentén - a jelentéskonstrukció különböző fázisainak a bemutatása a szimbolikus termelési apparátus néhány meghatározó intézményének elemzése révén. Fontos azonban azt is hangsúlyozni, hogy ezek a globális és lokális divat- és médiaipar erőterébe ágyazódó fázisok, melyek külön-külön is hierarchizáltak (pl. a divathetek, divatmagazinok vagy éppen a divatmodell-ügynökségek mezője), hatással vannak egymásra.

A bevezetőt követően a kulturális és divattermelés kollektív jellegét hangsúlyozó szociológiai munkákat tekintem át, majd ezt követően a divatproduktumok termékpályájának felvázolása révén egy, a divattanulmányok (fashion studies) művelői által mindeddig figyelmen kívül hagyott összefüggésre is felhívom a figyelmet, jelesül a divatbemutatók, divatmagazinok és az értékesítési színterek mint kulturális kontextusok jelentésközvetítő erejét tárgyalom. Noha tanulmányom megközelítése alapvetően elméleti, jelen szövegben nem elégszem meg a témával összefüggő fontosabb tudományos álláspontok puszta rekonstrukciójával. Az újítás igényével fellépve, ugyanakkor a citált szakirodalmakra jelentős mértékben támaszkodva, egy saját gondolati konstrukció körvonalazására teszek kísérletet a jelentéskonstrukció fázisainak bemutatása révén. A divattermékekhez tartozó szimbolikus jelentés megkonstruálásának folyamatát középpontba állító tanulmányom indokolttá tenné a fogyasztó mint a jelentéstermelésben önálló, hatalommal bíró aktív cselekvő szerepének a részletesebb tárgyalását, s ebből következően a mindennapi élet kontextusainak, azaz a jelentésteremtés hétköznapi kereteinek átfogó vizsgálatát. Azonban abból a megfontolásból, hogy a fogyasztás társadalmi kontextusai rendkívül sokrétüek, úgy vélem, hogy ezen keretek vizsgálata egy önálló tanulmány tárgyát kell hogy képezze. Továbbá azt is fontos tisztázni, hogy a kutatás tárgyává tett kulturális kontextusok mellett számos egyéb kontextus is létezik. Az elmúlt években például az internet expanziójának következtében a divatmagazinok mel-

3 Szimbolikus jelentés alatt az emocionális, esztétikai, ideológiai, illetve az életstílussal összefüggő szempontok alapján a fogyasztók fejében a termékről kialakult összképet értem.

4 E szöveg a termék és a márka szimbolikus tartalmát nem választja külön egymástól. Jóllehet marketingszempontból jelentős különbség van termék és márka között, azonban a potenciális vásárlók fejében a fogyasztás során az adott produktum szimbolikus tartalma a termék és a márkaszimbolizmus eredőjeként alakul ki. A fogyasztás is e logika mentén alakul, függetlenül attól, hogy magának a terméknek vagy a márkának van szimbolikus tartalma (Prónay 2011). 
lett a divatblogok szerepe is megnőtt. Jelen tanulmány azonban kifejezetten a divattermelés intézményesített, strukturális fontossággal bíró tradicionális „intézményeire” fókuszál. Többek között ennek köszönhető, hogy jelen szöveg pusztán a divatmagazinokkal foglalkozik, s nem bocsátkozik az egyéb mediális jelenségek jelentésteremtő szerepének mélyrehatóbb tárgyalásába. Reményeim szerint a tanulmány e reflexíven kezelt hiányosságával együtt is képes lesz komplex, s egyben meggyőző képet festeni a termékpálya fázisainak jelentésközvetítő erejéről.

\section{Kulturális és divattermelés szociológiai perspektívából}

A szociológiai vizsgálatok jelentős hangsúlyt fektetnek a kulturális termelés társadalmi és intézményi aspektusaira. A kulturális javak termelésének folyamatát megérteni szándékozó programadó munkák (pl. Becker 1982; Bourdieu 1993, 2013) arra hívják fel a figyelmet, hogy a kulturális termékek előállítása eredendően kollektív folyamatok eredményeként írható le, valamint hogy szimbolikus jelentésük és értékük is hasonlóképpen konstruált (De la Fuente 2007; Hesmondalgh 2006; Maanen 2009).

Becker 1982-ben megjelent Art Worlds címü munkájának fó állítása szerint a kulturális javak a közös konvenciókon nyugvó különböző szakmai szereplők közötti munkamegosztás és kooperáció kibontakozása révén születnek meg. A szerző a konvenciókat olyan mélyen bevésődött szokásokként definiálja, melyek révén a művészvilág résztvevői eldönthetik: mit, hogyan és kiknek a közremüködésével hoznak létre. A kulturális termelés megértéséhez azonban, szögezi le Becker, a társadalmi és intézményi kontextus - pontosabban fogalmazva mindazon szereplők csoportjának és feladatköreinek vizsgálata, akik hozzájárulnak a kulturális termék előállításához, még pontosabb fogalmazva azok, akik kitalálják a művet, akik elöállítják, akik a szükséges anyagi eszközöket szolgáltatják, és akik a mü közönségét alkotják - több mint kívánatos. Bourdieu The Field of Cultural Production (1993) címü, a kulturális erőterek elemzésének alapjait lefektető müvében, valamint $A$ müvészet szabályai (2013) címü történeti-szociológiai munkájában világossá teszi, hogy ágensek és intézmények csoportja együttesen járul hozzá a kulturális termékek szimbolikus jelentésének és értékének a meghatározásához. Következésképpen a kulturális vagy szimbolikus javak elöállítási folyamatának vizsgálata során, hangsúlyozza Bourdieu, nem csupán a termék materiális előállítójával kell számolni, hanem mindazon ágensek és intézmények összességével is, akik azzal, hogy kitermelik a művészet és az alkotó értékébe vetett hitet, a kulturális termék szimbolikus értékének és jelentésének létrehozásában is kulcsszerepet vállalnak. ${ }^{5} \mathrm{~A}$ fentebb tömören tárgyalt munkákra jelentős mértékben támaszkodva, a divattermelést megérteni és megmagyarázni szándékozó szociológiai munkák a divatproduktumok elóállításának folyamatát nem pusztán egyszemélyes vállalkozásként, mint inkább a különböző cselekvők és intézmények között létrejövő kollektív gyakorlatok sorozataként definiálják. Míg a klasszikus divatszociológiai munkák a divat terjedését és a divatjavak fogyasztását helyezik a vizsgála-

5 Becker és Bourdieu - mint a kortárs kultúraszociológia két meghatározó alakja - munkásságában közös, hogy mindketten a kulturális termelö alakjának demisztifikálására törekednek. Mindazonáltal, míg Becker a kulturális javak előállításának folyamatát a különböző szereplők közötti kooperáció kontextusában értelmezi, addig Bourdieu a kulturális termelők között feszülő konfliktust hangsúlyozza, mely a szimbolikus profitok elosztásáért folytatott permanens küzdelemből fakad (Maanen 2009). 
tok centrumába (Simmel 2004), addig a divattal foglalkozó kurrens társadalomtudományi munkák érdeklődésének homlokterében a divattermelésben érintett piaci közvetítők, valamint az általuk gyakorolt társadalmi és kulturális praxisok állnak (Entwistle 2009; Entwistle és Rocamora 2006; Entwistle és Wissinger 2012; Kawamura 2004, 2005; Mears 2011; Rocamora 2001).

Kawamura 2005-ben megjelent gyakorlatilag programadó Fashion-ology: An Introduction to Fashion Studies címü munkájában a divatvilágot az intézmények, szervezetek, szakmai csoportok, termelök, események és gyakorlatok koherens rendszereként interpretálja, azt hangsúlyozva, hogy a megnevezett komponensek mindegyike együttesen járul hozzá a divat termeléséhez (fashion production) - amely azonban nem összekeverendő a ruhagyártással (clothing production). ${ }^{6}$ A divattervező, hangsúlyozza Kawamura, minden kétség nélkül egyike azon kulcsfontosságú szereplőknek, akik megkülönbözetett pozíciót foglalnak el a divatrendszerben (fashion system) - egyedüli résztvevőként, az iparág egyéb szereplőivel és intézményeivel való kooperáció hiányában azonban képtelen a divat terjesztésére és a divattermékek értékének a kitermelésére. A divatproduktumok előállításának folyamata éppen ezért olyan kollektív cselekvések (collective activity) sorozataként interpretálható, amelyben egy bizonyos divattermék a tervező és a divattermelésben részt vevő szereplők és intézmények együttmüködése révén jön létre. ${ }^{7}$ Következésképpen, hangsúlyozza Kawamura, mint a kulturális termelés egyéb szféráiban, a divatrendszeren belül is a különböző szereplők és intézmények közötti komplex és nagyfokú munkamegosztásnak lehetünk tanúi.

A kulturális és a divattermelés kollektív jellegét hangsúlyozó szociológiai munkákkal egybehangzóan e tanulmány arra kíván rávilágítani, hogy a termékekhez tartozó szimbolikus jelentés megalkotója és kitermelője nem pusztán a produktum közvetlen előállítója. A jelentés megkonstruálásának folyamatában ugyan a kollekció üzenetét kialakító divattervezőnek jelentős szerepe van, fakadóan azonban abból, hogy a jelentés nem az adott termék materiális tulajdonságaiban rejlik, a kreáció pusztán önmagában nem képes a szimbolikus tartalmak jelölésére. Mivel a divattermékek képesek finom, metaforikus felhangok közvetítésére, önmagukban nehezen értelmezhetők, így nem feltételezhető egy mindenki által érthető és dekódolható általános jelentés. A divattermékeket társadalmi és kulturális kontextusba helyezve azonban némi bizonyosságot szerezhetünk jelentésükre vonatkozólag. ${ }^{8}$

6 Kawamura a ruhagyártás és a divattermelés mögött meghúzódó érdemi különbségeket a következő oppozíciók mentén definiálja: materiális és szimbolikus; megfogható és meg nem fogható; szükséglet és többlet. Tehát, míg a ruházat anyagi és fizikai termelés eredményeként, addig a divat különböző intézményesített, szimbolikus gyakorlatok révén teremtődik meg. Másképpen szólva, míg a ruha megfogható és explicit módon érzékelheto, addig a divat fizikai valójában nem létező; míg a ruházat szükséglet, mely elsősorban hasznossági funkciókat tölt be, addig a divat olyan többlet, melynek mindennapi életünkben leginkább szimbolikus szerep jut.

7 Hasonlóképpen érvel Blumer (1969) is Fashion: From Class Differentiation to Collective Selection címü klaszszikusnak számító divatszociológiai munkájában. Blumer értelmezésében a divat a divattervezők, a divatsajtó és a divattermékek fogyasztói között kialakuló társadalmi és intézményi viszonyok által teremtődik meg; pontosabban fogalmazva, a divat a fent megnevezett szereplők szelektív döntéseinek eredményeként jön létre.

8 A dzsentrifikált budapesti Madách tér szórakozóhelyeinek a közönségét adó, nagyrészt felső középosztálybeli, kreatív iparban dolgozó fiatalok közegében például az ocelotmintás műszőrme vagy a kilencvenes évek posztszocialista hangulatát idéző „susogós” melegítőalsó és a tarka selyeming az „öltözködési konvenciók elutasításának”, a „polgárpukkasztó tabudöntögetésnek”, vagy éppen a „test feletti önrendelkezésnek” a jelentéseit közvetíthetik, addig ezek a ruhadarabok egy dél-pesti lakótelepi környezetben már teljesen más jelentéseket kommunikálhatnak. 
A továbbiakban arra igyekszem rámutatni, hogy a divatproduktumok termékpályájának időben elkülönülő és egymásra épülő, ugyanakkor hatásukban egymást erősítő fázisai (1. ábra), úgymint a divatbemutatók (1. fázis), a divatmagazinok (2. fázis), valamint az értékesítési színterek (3. fázis) - melyek a globális és lokális divat- és médiaiparba ágyazódva külön-külön is hierarchikus viszonyrendszerbe szerveződö (al)mezöket alkotnak - olyan kulturális kontextusok, melyekben a divattermékek szimbolikus tartalommal itatódnak át.

1. ábra: A divatproduktumok termékpályájának fázisai

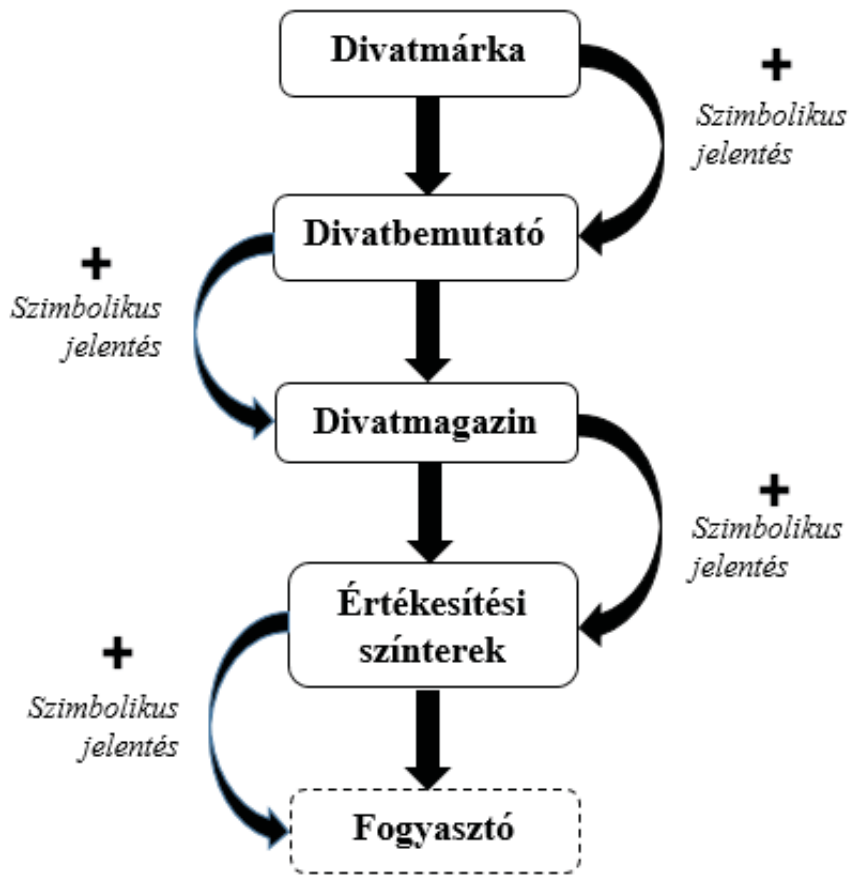

A következő alfejezetekben arra szeretném felhívni az olvasó figyelmét, hogy az egyes fázisok különböző észlelt elemei - úgymint a divatmodellek külső reprezentációja, a bemutatók társadalmi összetétele, a divatmagazinok képi világa és az azokban fellelhető írott diskurzusok, a tervezői darabokat értékesítö üzletek kirakatképe és belső arculata, az eladók külső reprezentációja és a kiszolgálás formája - olyan szimbolikus tartalmak hordozói, melyek a divattermékekhez tartozó jelentést közvetítik. Pontosabban fogalmazva, azt próbálom érzékeltetni az olvasóval, hogy az érzékelt kódok az esztétikai és gazdasági érték mellett a divatmárka által kialakított üzenetet is közvetítik. ${ }^{9}$

9 Ugyanakkor több mint fontos hangsúlyozni, hogy a fogyasztó mint aktív cselekvő saját társadalmi tapasztalatainak megfelelően önálló olvasatokat is létrehoz az adott üzenetekről. 


\section{1. fázis: A divatbemutató mint jelentésközvetítő kontextus}

Kawamura (2005) a fentebb már idézett munkájában a divatbemutatók és a képzőművészeti kiállítások közötti analógiára mutat rá. Értelmezése szerint miként egy kiállítás, éppúgy egy divatbemutató alkalmával a divatszakmák prominens és reprezentatív képviselői azért gyülnek össze, hogy szemrevételezzék, majd megítélés tárgyává tegyék a legújabb kollekciók darabjait. A szerző bemutatókra vonatkozó másik hangsúlyos állitása értelmében egy divattervező kizárólag a félévenként megrendezett divathetek valamelyikén való részvétellel képes megőrizni és újratermelni a divatrendszer hierarchiájában elfoglalt pozícióját. ${ }^{10}$ Entwistle és Rocamora (2006) - Kawamurával azonos álláspontot képviselve - a London Fashion Weeket a bourdieu-i mezőelméletből kiinduló etnográfiai vizsgálatuk során rámutatnak, hogy míg a divathét manifeszt funkciója a soron következő szezonok legújabb kollekcióinak bemutatása, addig látens funkciója az újonnan jövő ágensek legitimációval való felruházása és a domináns tervezők mezőben elfoglalt pozíciójának megerősítése. Azonban azáltal, hangsúlyozzák a szerzők, hogy a divatszerkesztők, divatkritikusok, az egyéb divatszakmák képviselöi és ünnepelt hírességek a divathét keretei között rendszeresen összegyülnek, nem pusztán a tervezők, hanem önmaguk mezőben elfoglalt pozícióját is megerősítik és újratermelik. ${ }^{11}$

A divatbemutatókkal foglalkozó kutatások fő áramát elsősorban tehát azon empirikus munkák alkotják, melyek szerint a bemutatók elsősorban legitimációs feladatköröket töltenek be. Arról azonban, hogy a divatbemutató mint kulturális kontextus milyen jelentésteremtő szerepet lát el, már nem esik szó. E tanulmány amellett érvel, hogy a divatbemutató - mint a legújabb kollekciók bemutatásának színhelye, s ekképpen mint a termékpálya első fázisa - nem pusztán legitimáló apparátusként funkcionál, hanem olyan kulturális kontextusként is, melyben a színpadra állított divattermékek a különböző észlelt kódok révén szimbolikus tartalommal töltődnek meg. Pontosabban fogalmazva, jelen szöveg arra kíván rámutatni, hogy a közönség társadalmi összetétele és a divatmodellek külső reprezentációja olyan jelentéshordozók, melyek nagymértékben hozzájárulnak ahhoz, hogy az iparág képviselői és a potenciális fogyasztók miként értelmezik a bemutatott kollekciót.

Ma már szinte közhelynek számít az a felismerés, hogy a kifutó körüli ülésrend az iparági szereplők közötti hatalmi és presztízsrelációkat jelöli (Skov 2006; Entwistle és Rocamora 2006, 2011). E megállapítás szerint, míg a kifutót szegélyező első sorok azoknak a prominens és reprezentatív résztvevőknek vannak fenntartva, akik jelenlétükkel emelik a bemutató fényét - tekintélyes szakújságírók, magazinok föszerkesztői, bloggerek és hírességek -, addig a hátsó sorokban a csekély befolyással rendelkező résztvevők foglalnak helyet, föként dizájnegyetemek ifú hallgatói és oktatói. Az azonban, hogy a bemutató társadalmi összetétele - vagyis a közönség soraiban helyet foglaló magas és alacsony státuszú résztvevők aránya miként járul hozzá ahhoz, hogy a divatszakmák képviselői és a potenciális vásárlók milyen jelentést tulajdonítanak a bemutatott kreációknak, már nem kerül a témához kapcsolódó társadalomtudományos kutatások fókuszába.

10 A divathét hozzávetőlegesen egy hétig tartó, évente két alkalommal (tavasz/nyár és ősz/tél) megtartott eseménysorozat, amely lehetőséget nyújt a tervezőknek, hogy legújabb kollekciójukat a kifutón is bemutathassák. A rendezvénysorozat New Yorkban veszi kezdetét, majd Londont és Milánót követően a sort Párizs zárja.

11 A szerzők továbbá arra is rámutatnak, hogy a divathét a divat termelésében aktív szerepet betöltő cselekvők csoportját magába foglalva, a mező határait és a benne részt vevő cselekvők egymáshoz viszonyított pozícióit kijelölve, lényegében nem más, mint a brit divatmező egészének megtestesülése egy területileg és időben behatárolt rendezvényen. 
Amint Podolny (2010) Status Signal című könyvében rámutat, a státusz egyik speciális sajátsága, hogy az egymással interakcióba lépő piaci szereplők között „átszivárog”: ha egy magas státuszú piaci szereplő egy alacsony státuszú piaci szereplővel lép interakcióba, a csoporton belül az alacsony státuszú piaci szereplő státusza növekedni fog. Podolny megállapításának újrakontextualizálása révén arra következtethetünk, hogy minél nagyobb számban vannak jelen a divatszakma magas státuszú képviselői - mértékadó magazinok föszerkesztői, divatírók és bloggerek, valamint széles körben ismert és ünnepelt hírességek - egy bizonyos divattervező bemutatóján, annál inkább érzékelik és értékelik az iparági szereplők és a potenciális fogyasztók is a bemutatott darabokat magas presztízsű produktumokként. A közönség társadalmi összetétele ily módon olyan jelentéshordozóként interpretálható, mely nagymértékben befolyásolja azt, hogy a divatszcéna és a végső fogyasztók milyen jelentést társítanak a bemutatott kreációkhoz.

Mears 2011-ben megjelent Pricing the Beauty: The Making of a Fashion Model címü résztvevő megfigyelésen alapuló munkájában a bourdieu-i fogalmi apparátust alkalmazva rámutat, hogy a divatmodell mező két ellentétes gazdasági logika alapján szerveződő almezőből, az ún. editorial, high-fashion és commercial, mass-market almezőkből épül fel. Míg a magas presztízsü editorial munkák elsősorban rangos divatbemutatókon való felvonulásból és mértékadó magazinokban való pózolásból, addig az alacsony szakmai presztízzsel rendelkező commercial munkák főként katalógusokban, nyomtatott és televíziós hirdetésekben való pózolásból állnak. A magas szakmai elismerés ellenére a kifutós modellek keresete jóval alacsonyabb a kommersz modellek keresetéhez viszonyítva. A nagy múltú Vogue magazinban való pózolással például egy kezdő modell naponta megközelítőleg 150 dollárt, ezzel szemben egy katalógusfotózás során egy kezdő modell akár 3000 dollárt is megkereshet, a divatheteken pedig az is előfordul, hogy a modelleket a bemutatott termékekkel javadalmazzák. A kifutós és magazinos munkák során felhalmozott szimbolikus profitok azonban hosszú távon olyan munkák megszerzéséhez vezethetnek, melyek szakmailag és gazdaságilag is egyaránt kifizetődnek (Mears 2011). Mears a fentebb tárgyaltokon túl arra is felhívja az olvasó figyelmét, hogy a két almező nem pusztán a munka és a pénzkereseti források jellege, hanem a modellek külső megjelenése által is differenciálódik: jelentős eltérések érzékelhetők a commercial és az editorial divatmodellek megjelenésében. Míg az editorial modellek külseje leginkább a szokatlan és különc (szakterminussal élve „edgy”), addig a commercial modellek kinézete a klasszikus és letisztult jelzőkkel írható le. Mears kutatásának középpontjában annak a folyamatnak a feltárása áll, amely során a divatmodellek piaci értéke megkonstruálódik, ebből fakadóan a modellek külső megjelenésének jelentésközvetítő ereje már kívül esik kutatásának tárgyán.

A fentebb ismertetett munkával szemben e tanulmány azt hangsúlyozza, hogy a divatmodell külső reprezentációja a termékekhez tartozó szimbolikus tartalom közvetítésének meghatározó eszköze. Vagyis a divatbemutató során alkalmazott modell megjelenése olyan vizuális kódként is értelmezhető, melynek funkciója a bemutatott kollekcióhoz tartozó szimbolikus tartalom jelölése. Például egy hazai divattervező, aki alapvetően a tömegízlést elutasító és a tömegből kitűnni akaró férfiakat célozza meg termékeivel, bemutatóin rendszerint olyan modellekkel dolgozik együtt, akik megjelenésükkel a tömegmédia, valamint a különböző reklám- és értékesítési apparátusok által mediatizált férfitestkép ideáját - kiváló példa erre a Marks \& Spencer reklámarca, David Gandy, aki megjelenésével a „maszkulin szívtipró” imázsát reprezentálja - kezdik ki (Melléklet 1-2. kép). 


\section{2. fázis: A divatmagazin mint jelentésközvetítő kontextus}

A fogyasztási trendek népszerüsítését vállaló divatmagazinok, magyarázatokkal kommentálva az új jelenségeket, az új márkák, tervezők és a divatirányzatok megismertetésére jöttek létre (Baudot 2000). A havi rendszerességgel megjelenő divatmagazinok tartalma éppen emiatt szorosan követi az aktuális szezonokat; míg a szerkesztők a márciusi kiadványt a legújabb tavaszi és nyári, addig a szeptemberi lapszámot az őszi és téli divatbemutatókon látott kollekciók darabjainak szentelik (Moeran 2006; Tungate 2004). Ebből következően a divatmagazin a termékpálya második olyan fázisaként is értelmezhető, melyben a bemutatott ruhadarabok szimbolikus tartalommal töltődnek meg. Ahogy számos tanulmány is hangsúlyozza (pl. Kawamura 2005; Moeran 2006; Tungate 2004), a divatmagazin, s mindenekelőtt a tartalom előállításáért felelős szerkesztő mint legitimáló autoritás, egy tervező új darabjának az aktuális lapszámba való beválogatásával azt kommunikálja az olvasóknak és egyúttal a szélesebb divatszakmának is, hogy az adott tervező olyannyira kreatív és tehetséges, hogy egyformán érdemes az olvasók és a divatszakma figyelmére. Ezen írások tehát szinte kizárólag arra helyezik a hangsúlyt, hogy a szaksajtóban való megjelenés egy olyan legitimáló aktus, amely növeli a divattervező piaci hierarchiában elfoglalt státuszát. A divatmagazinok ugyanakkor olyan jelentésközvetítők is, melyek - sajátos képi/vizuális reprezentációjukon, kiváltképp a címlapfotón mint a jelentést elsődlegesen közvetítő vizuális kódon (Melléklet 3-4. kép) és írott diskurzusaikon keresztül - a magazinokban bemutatott darabokat további szimbolikus tartalommal gazdagítják. Noha a divatlapok már a 18. század végétől jelen vannak, mégis csupán a 19. század második felétől tekinthetők a mai értelemben vett divatmagazinoknak. Eleinte a Les Modes, majd a huszadik század első felében a Harper's Bazaar és a Vogue divatmagazinok gyakoroltak komoly hatást a divat alakulására. A nyolcvanas évek elején azonban a fogyasztási szokások átalakulása és a társadalmi-kulturális pluralizálódás az egyéni ízléshez illeszkedő réspiacok megsokszorozódását és a piaci kínálat differenciálódását vonta maga után. A nagy múltú magazionok mellett, melyek föként a társadalomba mélyen beágyazott divatmárkák kreációinak bemutatására helyezik a hangsúlyt, az alternatív életstílus-magazinok - úgymint az i-D és a Dazed \& Confused befolyása is megnő, melyek formájukat és tartalmukat tekintve jelentős mértékben eltérnek a megszokott magazinoktól (Csipes 2006).

A fentiekből következően különbséget kell tennünk a havi rendszerességgel nagy példányszámban forgalomba kerülő, a nagyközönség létező igényeire reflektáló női stílusmagazinok (women's fashion magazine), valamint a korlátozott számban nyomtatott, kéthavonta megjelenö, leginkább a divatszakma bennfenteseinek és a különbözö életstíluscsoportoknak szóló divatmagazionok (niche fashion magazine) között (Lynge-Jorlén 2012). A női stílusmagazinok szerkesztői - ilyen pl. a fentebb már említett Harper's Bazaar magazin vagy az InStlye, Marie Claire, Elle magazinok - legföképpen a már elismert és kivételes ismertségnek örvendő tervezők általános közízlést kiszolgáló darabjait prezentáljak, melyekhez olyan modelleket és hírességeket válogatnak ki, akik fizikai adottságaikkal a klasszikus szépség társadalmilag konstruált ideálképét jelenítik meg. Ezzel szemben a divatipar képviselőinek és a különféle életstíluscsoportoknak szóló, képi világukban avantgárd, kísérletező és innovatív, tartalmukat tekintve a marginális témák felé forduló alternatív kiadványok - ezekre példák a fentebb említett $i-D$ és Dazed \& Confused magazionok - az újonnan jövő tervezők extravagáns kreációit állítják a centrumba, melyek hangsúlyosabbá tételéhez a külső megjelené- 
sükben a különcséget és a nem mindennapiságot megtestesítő divatmodelleket alkalmazzák (Lynge-Jorlén 2012). Mindebből az a megállapítás is levonható, hogy a különböző divatmagazinok eltérö jelentéseket kommunikálnak. Például az alapvetően avantgárd pozíciót elfoglaló, a különböző ifjúsági kultúrákat (youth culture) és azok öltözködési kultúráját, valamint az utcai stílusirányzatokat (street style) a középpontba állító, a szabad önkifejezést és önmegvalósítást propagáló $i-D$ magazinban való szereplés különböző jelentéseket közvetít, mint a középosztályos értékeket normatívának tartó, a „helyes és szép élet” társadalmilag idealizált eszményképét reprezentáló InStyle vagy Marie-Claire magazinokban való megjelenés.

A nyomtatott divattartalmat közvetítő kiadványok oldalain ugyan a fényképekkel elmondott történetek vannak túlsúlyban (McRobbie 1998), a vizuális diskurzus mellett az írott diskurzusnak is kulcsszerep jut (König 2006). Tervező és fogyasztó nyelve nem közös, kettejük közt szakadék tátong, ami a ruhadarab nem mindennapiságával, különösségével egyre csak mélyül. Az új divatirányzatok, melyek kezdetben furcsán hatnak, s melyeket az olvasók eleinte nehezen fogadnak be, mindig kommentárigényesek. A kollekciók értelmezésére (és értékelésére) szakosodott connoseaur - elősegítve a sokszor különös, első pillantásra nehezen érthető és befogadható ruhaköltemények recepcióját - szezonról szezonra interpretálja és magyarázatokkal látja el a legújabb kollekciók darabjait (Moeran 2013; Rocamora 2001). Az új kreációk megértését elősegítő kommentár azonban nem pusztán a termék könnyebb befogadását szolgáló adalék, hanem a divattermékhez tartozó szimbolikus jelentés megkonstruálásának egyik kulcsfontosságú aktusa. A divatírók a kollekciók megtekintését követően a magazinok hasábjain interpretálják a bemutatón látott kollekciókat, aminek során az értelmezés tárgyává tett darabok további jelentéstartalommal gazdagodnak.

\section{3. fázis: Az értékesítési színtér mint jelentésközvetítő kontextus}

Karpik (2010) szerint a divatpiacon, ahol az eredetiség szabályozóelvként müködik, ahol a gyakorlatok gyorsan változnak, ahol pofonegyszerű hibázni és az elhibázott gazdasági döntések költségesek, ott a tervezői darabok kiválasztásához és legitimálásához szükséges szaktudás több mint elengedhetetlen. Karpik értelmezése szerint a divattermékeket forgalmazó üzletek mint kapuőr szerepkört betöltő intézmények feladata megítélni és eldönteni, mely tervezői márkák kreációi érdemesek a tágabb társadalmi nyilvánosságra. A továbbiakban azt hangsúlyozom, hogy a divattermékeket forgalmazó üzletek nem pusztán legitimációs feladatkört betöltő piaci közvetítők, hanem olyan jelentésközvetítő „intézmények” is, melyek meghatározó szerepet játszanak a divatmárka által kialakított üzenet kommunikációjában. $\mathrm{Az}$ alábbiakban arra szeretnék rávilágítani, hogy a fogyasztás kontextusában észlelt kódok - úgymint a kirakat képe, az üzlet belső arculata, a kiszolgálás módja, valamint az üzletben dolgozók külső reprezentációja - olyan szimbolikus tartalmak hordozói, melyek nagymértékben befolyásolják azt, hogy a potenciális vásárlók milyen jelentést tulajdonítanak a kiállított termékeknek.

A meghatározott tematika köré szerveződő, az üzlet imázsára és belső tulajdonságaira reflektáló kirakat mint kiállító tér olyan vizuális kód, ami a benne elhelyezett darabokon és a kialakított hangulaton keresztül a kiállított divatproduktumokhoz tartozó üzenetet hangsúlyozza. Állításom szerint a kirakatban elhelyezett termékek száma és azok megvilágítása az alapján differenciálódik, hogy az adott üzlet milyen üzenetet kíván kommunikálni a ki- 
állított termékekről. A tömegdivattermékeket forgalmazó „fast fashion” üzletek kirakatának mindent átható fényáradata például a bőséges áruválasztékon túl azt a jelentést is közvetíti, hogy a kirakatban elhelyezett divattermékek viselésével a vásárló a társadalom többi tagjával egy és ugyanazon ízlésben osztozik. Ezzel szemben az egyéni ízléshez illeszkedő tervezői darabokat értékesítő üzletek kirakatában a termékek megvilágítása visszafogott, a lámpák úgy vannak beállítva, hogy kizárólag egy-egy terméket vagy egy bizonyos összeállítást világítsanak meg. Az adott divatterméket a centrumba állító kirakatkép az egyediség, a többiektől való különbözés jelentéseit közvetíti (Fiske 1989). A fogyasztás kontextusában a kirakatkép mellett a belső design is lényeges jelentésközvetítő eszközként funkcionál. Mivel az enteriőr összhangban van azzal a jelentéssel, amit a divatmárkák a bemutatott darabokkal közvetíteni akarnak, ezért az üzlet belső dekorációja sohasem neutrális tényező (Vernet és de Wit 2007). Például egy, a letisztult formavilágáról és időtálló darabjairól ismert svéd márka - mely termékeivel a kreatív iparban dolgozó designérzékeny fogyasztói réteget célozza meg - Andrássy úti üzletébe belépve figyelmünket egyből megragadja az üzlet egyszerü, minden hivalkodást nélkülöző belső képe (Melléklet 5. kép). A minimalista berendezés, a fehér felületek, a világosbarna faelemek, valamint a króm ruhafogasok egytől egyig a márka által sugallni kívánt üzenetet, azaz a „funkcionalitást” és a „modernséget” hangsúlyozzák. ${ }^{12}$

A márka által kialakított üzenet kommunikációjában a külső és a belső terek vizuális reprezentációja mellett az eladók külső megjelenése és a kiszolgálás módja is meghatározó jelentőséggel bír. Számos üzleteben az eladók a megvásárlásra kínált legújabb termékeket viselve szolgálják ki a potenciális vásárlókat, így világos képet adva arról, hogy melyek a legújabb termékek, s hogy miként kell azokat a legutóbbi divat- és stílusirányzatoknak megfelelően hordani. Az eladó külső reprezentációján túl a jelentés közvetítésének további kulcsfontosságú aktusa a kiszolgás módja. A személyes értékesítés során az eladó mint „személyes stylist” gyakran például öltözködési és stílustanácsokkal látja el az üzletbe betérő vásárlókat, ami a divatirányzatokban való jártasság, azaz a „szakértelem” és a „hozzáértés” jelentéseit kommunikálja (Pettinger 2004).

\section{Összefoglalás}

Tanulmányomban egy a divattermeléssel foglalkozó kurrens társadalomtudományi kutatások által mindeddig figyelmen kívül hagyott összefüggésre: a kulturális kontextusokként értelmezett divatbemutatók, divatmagazinok és értékesítései színterek jelentésközvetítö erejére igyekeztem rámutatni. Noha a tanulmány megközelítése alapvetően elméleti volt, a fenti szöveg nem pusztán a témával kapcsolatos fontosabb álláspontok szakirodalmi rekonstrukciójára vállalkozott. Az újítás igényével fellépve, a tárgyalt tudományos munkákra nagymértékben támaszkodva, egy saját gondolati konstrukció körvonalazására tett kísérletet. E bevezető tanulmány fó célkitüzése annak a termékpályának a széles ecsetvonásokkal történő felvázolása volt, amelyen végighaladva a divattervező kezei közül kikerülő kreációk - a fentebb megnevezett időben elkülönülő és egymásra épülő, ugyanakkor hatásukban egymást erősítő fázisokon keresztül - szimbolikus tartalommal töltődnek meg.

12 Erről lásd részletesebb a márka vezérigazgatójával készült interjút (Howarth 2014). 
A fenti szöveg első részében a tanulmány szempontjából meghatározó elméleti referenciák főbb elemeinek az összefoglalására tettem kísérletet, majd az azt követő alfejezetekben arra igyekeztem rámutatni, hogy a divatbemutatók, divatmagazinok és értékesítési színterek különböző elemei - úgymint a divatmodellek külső reprezentációja, a bemutatók társadalmi összetétele, a divatmagazinok képi világa és az azokban fellelhető írott diskurzusok, a divattermékeket értékesítö üzletek kirakatképe és belső arculata, az eladók külső reprezentációja és a kiszolgálás formája - olyan jelentéshordozók, melyek amellett, hogy jelölik a termékek feltételezett esztétikai és gazdasági értékét, a divatmárka által kialakított üzenet közvetítésére is szolgálnak.

\section{Hivatkozott irodalom}

Baudot, Francois (2000): Divat a XX. században. Budapest: Park Könyvkiadó.

Baudrillard, Jean (1981): For a Critique of the Political Economy of the Sign. St. Louis, Mo: Telos Press Ltd.

Becker, Howard S. (1982): Art Worlds. Berkley: University of California Press.

Blumer, Herbert (1969): Fashion: From Class Differentiation to Collective Selection. The Sociological Quarterly 10(3): 275-91.

Bourdieu, Pierre (1993): The Field of Cultural Production. Cambridge: Polity Press.

Bourdieu, Pierre (2013): A müvészet szabályai. Az irodalmi mezö genezise és struktúrája. Budapest: Budapesti Kommunikációs és Üzleti Főiskola.

Brown, Elspeth H. (2012): From Artist's Model to the 'Natural Girl': Containing Sexuality in Early-TwentiethCentury Modelling. In Fashioning Models, Image, Text and Industry. Joanne Entwistle és Elizabeth Wissinger (szerk.). London: Berg. 37-55.

De la Fuente, Eduardo (2007): The 'New Sociology of Art': Putting Art Back into Social Science Approaches to the Arts. Cultural Sociology 1(3): 409-425. DOI: https://doi.org/10.1177/1749975507084601.

Douglas, Mary és Isherwood, Baron (1979): The World of Goods. Towards an Anthropology of Consumption. London and New York: Routledge.

Du Gay, Paul és Pryke, Michael (2002): Cultural Economy. Cultural Analysis and Commercial Life. London: Sage Publications.

Dubuisson-Quellier, Sophie (2007): The Shop as Market Space. The Commercial Qualities of Retail Architecture. In Boutiques and Other Retail Spaces. The Architecture of seduction. David Vernet és Leontine de Wit (szerk.). London és New York: Routledge. 16-33.

Enwistle, Joanne és Rocamora, Agnés (2006): The Field of Fashion Materialized: A Study of London Fashion Week. Sociology 40(4): 735-751. DOI: https://doi.org/10.1177/0038038506065158.

Enwistle, Joanne (2002): The Aesthetic Economy. The Production of Value in the Field of Fashion Modelling. Journal of Consumer Culture 2(3): 317-339. DOI: https://doi.org/10.2752/9780857854148/aesecofash0004.

Evans, Caroline (2001): The Enchanted Spectacle. Fashion Theory 5(3): 271-310. DOI: https://doi.org/10.2752/ 136270401778960865.

Featherstone, Mike (1991): Consumer Culture and Postmodernism. London: Sage.

Fiske, John (1989): Reading the Popular. London: Routledge.

Garnham, Nicholas (2005): From Cultural to Creative Industries. An Analysis of the Implications of the "Creative Industries" Approach to Arts and Media Policy Making in the United Kingdom. International Journal of Cultural Policy 11(1): 15-29. DOI: https://doi.org/10.1080/10286630500067606.

Hesmondalgh, David (2006): Bourdieu, the Media and Cultural Production. Media, Culture \& Society 28(2): 211-231. DOI: https://doi.org/10.1177/0163443706061682.

Hesmondalgh, David (2013): The Cultural Industries. London: Sage

Hirschman, Elizabeth C. (1981): Comprehending Symbolic Consumption: Three Theoretical Issues. In Symbolic Consumer Behavior. Elizabeth C. Hirschman és Morris B. Holbrook (szerk.). New York, NY: Association for Consumer Research, 4-6. Interneten: http://www.acrwebsite.org/search/view-conference-proceedings.aspx?Id=12219 (letöltve: 2017. június 15.) 
Hirschman, Elizabeth C. (1986): The Creation of Product Symbolism. In Advances in Consumer Research Richard J. Lutz, Provo (szerk.). UT: Association for Consumer Research 327-331 Interneten: http://acrwebsite.org/volumes/6513/volumes/v13/NA-13 (letöltve: 2017. június 15.)

Howarth, Dan (2014): "Design and Architecture Has Been a Key Influence" Says COS Managing Director. Dezeen.com. Interneten: https://www.dezeen.com/2014/11/05/cos-marie-honda-interview-fashion-designarchitecture-branding-nendo-serpentine-numen-for-use/ (letöltve: 2018. január 10.).

Karpik, Lucien (2010): Valuing the Unique. The Economics of Singularities. New Jersey: Princeton University Press. Kawamura, Yuniya (2004): The Japanese Revolution in Paris Fashion. Oxford: Berg.

Kawamura, Yuniya (2005): Fashion-ology. An Introduction to Fashion Studies. Oxford: Berg.

König, Anna (2006): Glossy Words: An Analysis of Fashion Writing in British Vogue. Fashion Theory 10(12): 205-224. DOI: https://doi.org/10.2752/136270406778051085.

Lash, Scott M. és Urry, John (1994): Economies of Signs and Space. London: Sage.

Lury, Celia (1996): Consumer Culture. Cambridge: Polity.

Lynge-Jorlén, Ane (2012): Between Frivolity and Art: Contemporary Niche Fashion Magazines. Fashion Theory 16(1): 7-28. DOI: https://doi.org/10.2752/175174112x13183318404104.

McRobbie, Angela (1998): British Fashion Design. Rag Trade or Image Industry? London: Routledge.

Mears, Ashley (2011): Pricing Beauty. The Making of a Fashion Model. London: University of California Press.

Moeran, Brian (2004): A Japanese Discourse of Fashion and Taste. Fashion Theory 8(1): 35-62. DOI: https://doi. org/10.2752/136270404778051898.

Moeran, Brian (2006): More than Just a Fashion Magazine. Current Sociology (54)5: 725-744. DOI: https://doi. org/10.1177/0011392106066813.

Nixon, Sean (2003): Advertising Cultures. Gender, Commerce, Creativity. London: Sage.

O'Connor, Justin (2010): The Cultural and Creative Industries: A Literature Review. 2. kiadás. Newcastle: Creativity, Culture and Education Series.

Parmentier, Marie-Agnés és Fischer, Eileen (2007): Working to Consume the Model Life: Consumer Agency under Scarcity. In Consumer Culture Theory 11. Research in Consumer Behaviour Series, R.W. Belk és J.F. Sherry Jr (szerk.). Oxford: Elsevier. 23-39.

Pettinger, Lynne (2004): Brand Culture and Branded Workers: Service Work and Aesthetic Labour in Fashion Retail. Consumption Markets \& Culture 7(2): 165-184. DOI: https://doi.org/10.1080/1025386042000246214.

Podolny, Joel M. (2005): Status Signals. A Sociological Study of Market Competition. New Jersey: Princeton University Press.

Power, Dominic és Scott, Allen J. (2004): Cultural Industries and the Production of Culture. London: Routledge.

Prónay, Szabolcs (2011): Ragaszkodás és én-alakítás a fiatalok fogyasztásában. A fogyasztói lojalitás és az énkép közötti kapcsolat vizsgálata. (Doktori dolgozat.). Szeged: Szegedi Tudományegyetem Gazdaságtudományi Kar. Interneten: http://doktori.bibl.u-szeged.hu/847/1/disszertacio_Pronay.pdf (letöltve: 2017. augusztus 4.)

Rocamora, Agnes (2001): High Fashion and Pop Fashion: The Symbolic Production of Fashion in Le Monde and The Guardian. Fashion Theory 5(2): 123-142. DOI: https://doi.org/10.2752/136270401779108626.

Simmel, Georg (2001): A divat. In Válogatott társadalomelméleti tanulmányok. Budapest: Novissima Kiadó. $180-200$

Skov, Lise et al. (2006): The Fashion Show as an Art Form. Creative Encounters Working Paper (32): 1-37.

Soley-Beltran, Patrícia (2012): Performing Dreams: A Counter-History of Models as Glamour's Embodiment. In Fashioning Models, Image, Text and Industry. Joanne Entwistle és Elizabeth Wissinger (szerk.). London: Berg. 97-115.

Van Maanen, Hans (2009): How to Study Art Worlds. On the Societal Functioning of Aesthetic Values. Amsterdam: Amsterdam University Press.

Vernet, David és De Witt, Leonite (2007): Boutiques and Other Retail Spaces. The Architecture of seduction. London and New York: Routledge. 


\section{Melléklet}

1-2. kép. Zsigmond Dora Menswear Spring/Summer '18
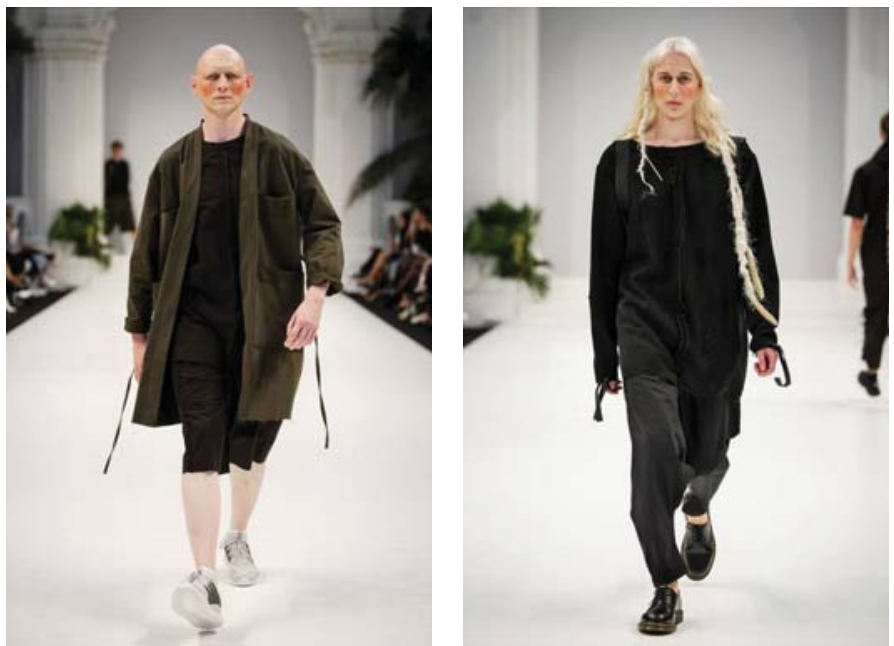

Forrás: facebook.com ${ }^{13}$

3. kép. A brit i-D magazin címlapja: The Female Gaze Issue, no. 344, 2016

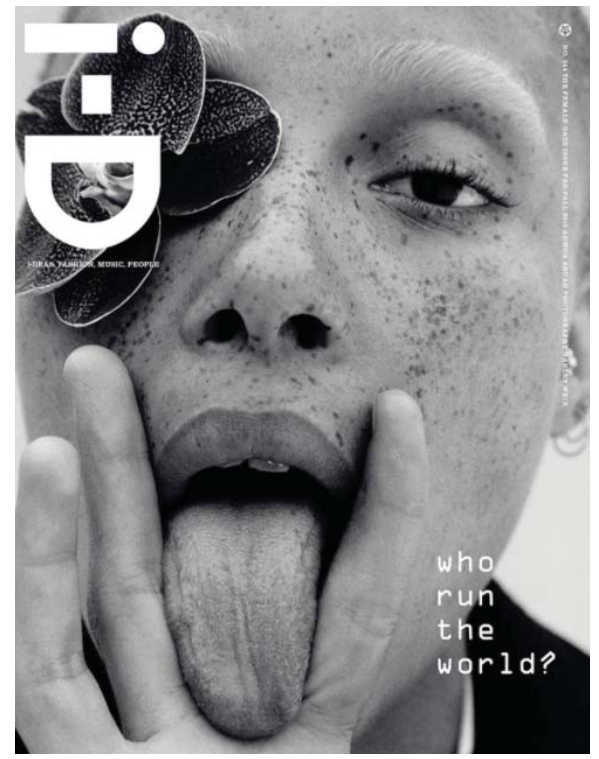

Forrás: i-d.vice.com ${ }^{14}$

$13 \mathrm{https} / /$ www.facebook.com/pg/mbfwce/photos/?tab=album\&album_id=1062906840515340 $14 \mathrm{http}: / /$ covers.i-d.co/cover/344/1 
4. kép. Az amerikai InStyle magazin címlapja, 2017. február

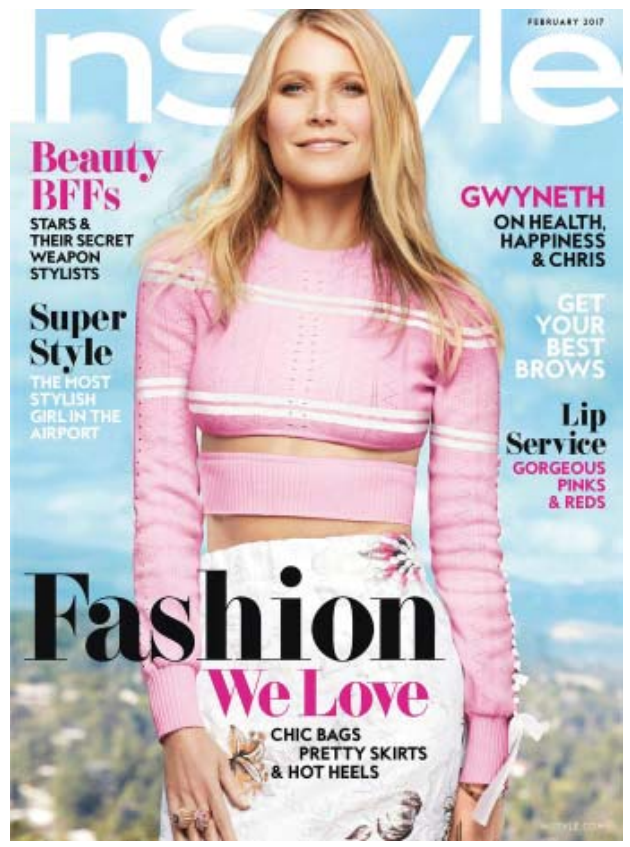

Forrás: instyle.com ${ }^{15}$

5. kép. Az Andrássy úti COS üzlet belső tere

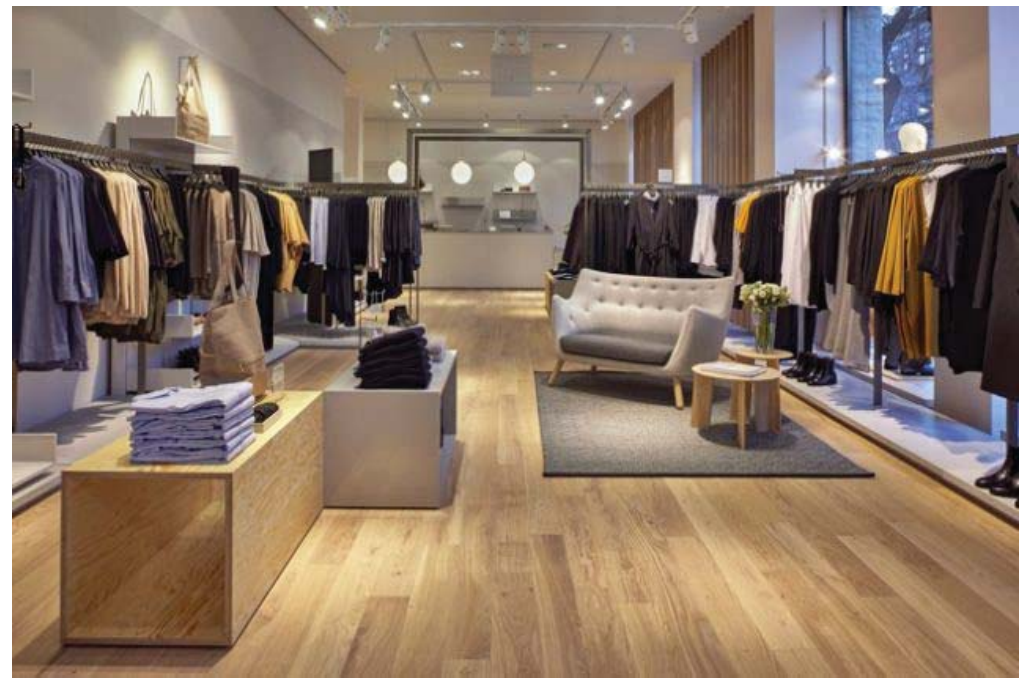

Forrás: design.hu ${ }^{16}$

$15 \mathrm{http} / / / \mathrm{www}$.instyle.com/celebrity/gwyneth-paltrow-february-cover-story

$16 \mathrm{https} / / /$ design.hu/magazin/divat-ekszer/noi-divat/megnyilt-a-cos-budapesten 